\title{
Detection of norovirus in stool samples by RT- PCR in 5 disease centers in Iran
}

\author{
Saadat Adabian ${ }^{1}$, Fatemeh Fallah ${ }^{1,2^{*}}$, Latif Gachkar ${ }^{2}$, Farzaneh Jadali', S Rafiei Tabatabaei ${ }^{1}$, Narges Esmaeilnejad ${ }^{1}$ \\ From First International Science Symposium on HIV and Infectious Diseases (HIV SCIENCE 2012) \\ Chennai, India. 20-22 January 2012
}

\section{Background}

Noroviruses are a group of viruses that cause gastroenteritis (illness that usually includes diarrhea and/or vomiting) in people. Gastroenteritis means inflammation of the stomach and small and large intestines. Many different viruses can cause gastroenteritis, including rotaviruses; noroviruses; adenoviruses, types 40 and 41 ; sapoviruses; and astroviruses. Current techniques used for detection of noroviruses in stool samples include multi-step viral RNA extraction and purification followed by reverse transcriptase-polymerase chain reaction (RT-PCR). The aim of this study is the detection of norovirus in stool samples by RT-PCR in 5 disease centers in Iran.

\section{Methods}

In this descriptive study, 2170 stool samples of patients consulting for acute gastroenteritis at a pediatric hospital in 5 cities of Iran were enrolled. The mean age of the study population was 48 months with an age range of 30 days to 4 years. Fecal specimens were collected within $24 \mathrm{hrs}$ of admission. The specimens were frozen, sent to the laboratory, and then stored at $-80^{\circ} \mathrm{C}$ until being tested for norovirus.

\section{Results}

RT-PCR was evaluated with 2170 stool samples containing 90 (4.14\%) norovirus-positive (0.97\% Tehran, 0.64\% Tabriz, 0.18\% Mashhad, 1.57\% Shiraz, 0.78\% Bandar Abbas). The RT-PCR was validated with published primers for norovirus (JV12/JV13). In both retrospective and prospective settings, the RT-PCR was equally sensitive and specific in detecting norovirus.

\footnotetext{
* Correspondence: fallah@pirc.ir

${ }^{1}$ Pediatric Infection Research Center, Shahid Beheshti Univ. M.C, Tehran, Iran
} Full list of author information is available at the end of the article

\section{Conclusion}

Acute gastroenteritis can be caused by norovirus. It has to be attending to vaccination against norovirus after rotavirus.

\section{Author details}

'Pediatric Infection Research Center, Shahid Beheshti Univ. M.C, Tehran, Iran. ${ }^{2}$ Infectious Disease \& Tropical Medicine Research Center, Tehran, Iran.

Published: 4 May 2012

doi:10.1186/1471-2334-12-S1-010

Cite this article as: Adabian et al:: Detection of norovirus in stool samples by RT-PCR in 5 disease centers in Iran. BMC Infectious Diseases 2012 12(Suppl 1):010.
Submit your next manuscript to BioMed Central and take full advantage of:

- Convenient online submission

- Thorough peer review

- No space constraints or color figure charges

- Immediate publication on acceptance

- Inclusion in PubMed, CAS, Scopus and Google Scholar

- Research which is freely available for redistribution
() Biomed Central 